\title{
Extreme Ultraviolet (EUV)-Resist Material Based on Noria (Water Wheel-like Macrocycle ) Derivatives with Pendant Alkoxyl and Adamantyl Ester Groups
}

\author{
Hiroto Kudo ${ }^{1}$, Nobumitsu Niina ${ }^{2}$, Tomoharu Sato $^{2}$, Hiroaki Oizumi ${ }^{3}$, Toshiro Itani $^{3}$, \\ Takuro Miura ${ }^{4}$, Takeo Watanabe ${ }^{4}$ and Hiroo Kinoshita ${ }^{4}$,
}

\author{
${ }^{1}$ Department of Chemistry and Materials Engineering, Faculty of Chemistry, \\ Materials and Bioengineering, Kansai University, 3-3-35, Yamate-cho, Suita-shi, Osaka, 564-8680, Japan. \\ ${ }^{2}$ Department of Material and Life Chemistry, Faculty of Engineering, \\ Kanagawa University, Rokkakubashi, Kanagawa-ku, Yokohama, 221-8686, Japan. \\ ${ }^{3}$ Selete (Semiconductor Leading Edge technologies, Inc.) Research Dept.3 16-1, \\ Onogawa, Tsukuba, Ibaraki 305-8569, Japan. \\ ${ }^{4}$ Laboratory of Advanced Science and Technology for Industry, \\ University of Hyogo, 1-1-2 Kouto, Kamigouri, Ako-Gun, Hyogo, Pref 678-1205, Japan. \\ *E-mail: kudoh@kansai-u.ac.jp
}

Keywords : noria, adamantane, chemically amplification, extreme ultraviolet, resist

\section{Introduction}

Photolithography system employing electron beam (EB) and shorter wavelength lasers, such as $\operatorname{KrF}(\lambda=248 \mathrm{~nm}), \operatorname{ArF}(\lambda=193 \mathrm{~nm})$, and extreme ultraviolet (EUV, $\lambda=13.5 \mathrm{~nm}$ ) have been expected to offer higher resolution pattern. According to the developments of photolithography system, the development of new resist materials have been required. Very recently, extreme ultraviolet (EUV) laser has been expected to offer higher resolution pattern with less than about $20 \mathrm{~nm}$ resolution. However, there is a serious problem among the resolution of pattern, sensitivity of the photo-chemical reaction, and roughness of the pattern, i.e., these relationships are well known as "trade-off". To overcome this "trade-off", many molecular glasses such as calixarenes, ${ }^{1-10}$ dendritic oligomers, ${ }^{11-18}$ low-molecular-weight oligomers, ${ }^{19,20}$ and fullerenes ${ }^{21}$ have been reported and their resolutions showed about $50 \mathrm{~nm}$ regions. Recently, we could design a ladder type cyclic oligomer "noria" (noria = water wheel in Latin), ${ }^{22}$ and examined the synthesis, physical properties, and patterning properties of noria derivatives with pendant $t$-butyl ester groups, ${ }^{23,24} t$-butyloxycarbonyl groups, ${ }^{25}$ adamantyl ester groups, ${ }^{26,}{ }^{27}$ cyclohexyl acetal moiety, ${ }^{28}$ and oxetanyl groups ${ }^{29}$ using electron beam (EB) or EUV exposure systems. Furthermore, noria derivative with pendant a protective group could achieve to offer clear $22 \mathrm{~nm}$ resolution pattern using EUV exposure system. $^{30}$

Meanwhile, noria analogues with pendant twelve alkoxyl groups could be synthesized by the condensation reaction of $1,5^{-}$ pentanedial with 3-methoxyphenol or 3-ethoxyphenol under dynamic covalent chemistry (DCC) system. ${ }^{31}$ In DCC system, noria derivatives with pendant twelve methoxy groups (noriamp) and twelve ethoxy groups (noriaep) could be obtained selectively and their solubility and film-forming ability are superior to those of noria. These results expected that noriamp and noriaep derivatives with pendant protective groups can have superior resist properties using EUV exposure system.

In this communication, we synthesized noriamp derivatives (noriamp- $\mathrm{AD}_{\mathrm{n}}$ ) with pendant adamantyl ester groups, and their physical properties and EUV patterning properties were examined. 


\section{Experimental Materials.}

3-Methoxyphenol (MP), tetrabutylammonium bromide (TBAB), and propylene glycol methyl ether acetate (PGMEA) were purchased from Tokyo Chemical Industry Co., Ltd (Tokyo, Japan). 1,5-Pentanedial $(50 \%$ aqueous solution) and 1-methyl-2-pyrrolidone (NMP) were purchased from Kanto Chemical. Co., Inc (Tokyo, Japan). Trifluoroacetic acid (TFA), trioctylamine (TOA), and potassium carbonate $\left(\mathrm{K}_{2} \mathrm{CO}_{3}\right)$ were purchased from Wako Pure Chemical Industries, Ltd (Osaka, Japan). 2-Bromoacetyloxy-2-methyladamantane (BMA) was obtained from Idemitsu Kosan Co., Ltd (Tokyo, Japan). Anhydrous magnesium sulfate, $\left(\mathrm{MgSO}_{4}\right)$ was purchased from Yoneyama Yakuhin Kogyo Co., Ltd (Osaka, Japan). Chloroform and methanol were purchased from Godo Co., Ltd (Tokyo Japan). Triphenylsulfonium triflate (TPS-Tf) was obtained from JSR (Tokyo, Japan). Triphenylsulfonium nonafrate (TPS-Nf) was donated from Selete (Ibaraki, Japan). All chemicals were used as commercial grade without further purification.

\section{Measurements.}

Infrared ray (IR) spectra were taken by NICOLET 380 FT-IR (ThermoFisher Scientific Inc. USA). Hydrogen magnetic resonance $\left({ }^{1} \mathrm{H}\right.$ NMR) spectra were recorded on a JNM-ECA-600 (JEOL Ltd. Japan) by dissolving samples in deuterated $\mathrm{CHCl}_{3}$ and dimethylsulfoxide (DMSO). Matrix-assisted laser desorption/ionization time-offlight mass spectrometry (MALDI-TOF MS) analysis was carried with an AXIMA-CFR plus (Shimazu Co. Japan) in positive mode. Thermogravimetric analysis (TGA) was performed on EXSTAR 6000 (Seiko Instruments Inc. Japan) with the sample in an inert nitrogen atmosphere. Prior to testing, the samples were dried at $100{ }^{\circ} \mathrm{C}$ for $20 \mathrm{~min}$ under nitrogen and then thermally ramped in the TGA to $600{ }^{\circ} \mathrm{C}$ at a heating rate of $10{ }^{\circ} \mathrm{C} / \mathrm{min}$. The glass transition temperature $\left(T_{\mathrm{g}}\right)$ was measured on a Seiko Instruments differential scanning calorimeter (DSC) model EXSTAR6000/DSC6200 at heating rate of 10 ${ }^{\circ} \mathrm{C} / \mathrm{min}$ under nitrogen. Size exclusion chromatography (SEC) was performed by HLC-8220 (Tosoh Co. Japan) having a Shodex Asahipak GF-510 HQ(7.5 i.d. $\times 300 \mathrm{~mm})$ and two GF-310 HQ columns (7.5 i.d. $\times 300 \mathrm{~mm}$ ), and the DMF solution containing $20 \mathrm{mM}$ anhydride $\mathrm{LiBr}$ and $20 \mathrm{mM} \mathrm{H}_{3} \mathrm{PO}_{4}$ was used as a mobile phase. Film thickness was measured by ellipsometer (DHA-OLX, Mizojiri Optical Co., Ltd.). The EUV lithography was performed by small field exposure tool (SFET) with 0.3 mumerical aperture connected to a coater/developer track system ACT-12 in a chemically controlled environment. The scanning electron microscope (SEM) images were observed by critical-dimension SEM (CD-SEM, S9380II and S9220, Hitachi). Powder X-ray diffusion (PXRD) analysis was performed by MultiFlex (Rigaku Corporation) on the room temperature.

Synthesis of noria ${ }_{M P}$.

A mixture of 1,5-pentanedial (50\% in water, 10 g, $50 \mathrm{mmol}), 3$-methoxyphenol (24.8 g, $200 \mathrm{mmol})$, and TFA ( $37.5 \mathrm{~g}, 330 \mathrm{mmol})$ as an acid catalyst in chloroform $(50 \mathrm{~mL})$ was stirred at reflux for 48 hours. The reaction solution was poured into methanol, and the precipitation was collected by filtration and then dried in vacuo at $60{ }^{\circ} \mathrm{C}$ for 24 hours. The yield was $12.2 \mathrm{~g}(79 \%)$. IR $\left(\mathrm{KBr}, \mathrm{cm}^{-1}\right)$ : $3411(v \mathrm{OH}), 2998$ ( $v \mathrm{C}-\mathrm{H}$ aromatic), 2933 and 2858 ( $v$ C-H aliphatic), 1616 and $1589(v \mathrm{C}=\mathrm{C}$ aromatic), 1294 and 1100 ( $v$ C-O-C ester). ${ }^{1} \mathrm{H}$ NMR $\left(600 \mathrm{MHz}\right.$, TMS, DMSO- $\left.d_{6}\right): \delta(\mathrm{ppm})$ 0.44-3.02 (m, 36H, - $\mathrm{CH}_{2} \mathrm{CH}_{2} \mathrm{CH}_{2}$ ), 3.24-3.99 (m, $\left.36 \mathrm{H},-\mathrm{OCH}_{3}\right), 4.04-4.86(\mathrm{~m}, 12 \mathrm{H},>\mathrm{CH}), 5.53-7.52$ $(\mathrm{m}, \quad 24 \mathrm{H}, \quad \operatorname{arH}), \quad 7.80-9.67 \quad(\mathrm{~m}, \quad 12 \mathrm{H}, \mathrm{OH})$. MALDI-TOF mass: calcd for $\left[\text { noria }_{M P}+\mathrm{Na}\right]^{+}$: 1897.2, found: 1897.2.

\section{Synthesis of noria ${ }_{M P}$ derivatives with pendant adamantyl ester groups.}

Typical procedure for synthesis of noria $_{\mathrm{MP}}-\mathrm{AD}_{18}$; A mixture of noria $\mathrm{MP}_{\mathrm{MP}}(8.0 \mathrm{~g}, 4.2$ $\mathrm{mmol}), \mathrm{K}_{2} \mathrm{CO}_{3}(8.2 \mathrm{~g}, 60 \mathrm{mmol})$, and TBAB $(0.064$ g, $0.2 \mathrm{mmol})$ in NMP $(95 \mathrm{~mL})$ was stirred at $60{ }^{\circ} \mathrm{C}$ for $3 \mathrm{~h}$. After that, a solution of BMA ( $4.3 \mathrm{~g}, 15$ mmol) in NMP (5 mL) was added slowly to resulting mixture, and was stirred at $60{ }^{\circ} \mathrm{C}$ for $48 \mathrm{~h}$. The obatined solution was poured into chloroform, and washed with $0.1 \mathrm{M}$ oxalic acid aqueous solution and water. The organic layer was dried over $\mathrm{MgSO}_{4}$, and concentrated by rotary evaporator. The concentrated solution was added to methanol to obtain the white solid. The resulting precipitate was collected by vacuum filtration, and dried at $60{ }^{\circ} \mathrm{C}$ in vacuo for $12 \mathrm{~h}$. The degree of introduction of adamantyl ester groups (DI) was calculated by ${ }^{1} \mathrm{H}$ NMR integration ratios of the methyl protons of methoxy moieties, and methyl and methylene protons of noria $\mathrm{MP}_{\mathrm{MP}}$ and adamantyl ester moieties. DI $=18 \%$. The yield was $6.7 \mathrm{~g}$ (68\%). IR (film, $\left.\mathrm{cm}^{-1}\right) ; 3402(v \mathrm{OH}), 2997(v \mathrm{C}-\mathrm{H}$ aromatic) 2927 and 2861 ( $v$ C-H aliphatic), 1748 and $1724(v \mathrm{C}=\mathrm{O}$ ester), 1615 and $1588(v \mathrm{C}=\mathrm{C}$ aromatic), 1296 and 1054 ( $v$ C-O-C ether), $1102(v$ $\mathrm{O}=\mathrm{C}-\mathrm{O}-\mathrm{C}$ ester). ${ }^{1} \mathrm{H}$ NMR $\left(600 \mathrm{MHz}, \mathrm{CDCl}_{3}\right.$, TMS $) \delta(\mathrm{ppm})=0.34-2.37\left(\mathrm{~m},-\mathrm{CH}_{3}\right.$ and $-\mathrm{CH}_{2^{-}}$, 
72.7H), $3.51-3.83\left(\mathrm{~m},-\mathrm{OCH}_{3}, 36 \mathrm{H}\right), 4.22-4.53$ (broad $\left.\mathrm{m},-\mathrm{O}-\mathrm{CH}_{2}-\mathrm{C}=\mathrm{O},>\mathrm{CH}, 16.3 \mathrm{H}\right), 6.20-$ $6.30(\mathrm{~m}, \mathrm{ArH}, 24 \mathrm{H}) \cdot 7.31$ (broad, $-\mathrm{OH}, 9.8 \mathrm{H}) \cdot M_{\mathrm{n}}=$ $2172, M_{\mathrm{w}} / M_{\mathrm{n}}=1.09$.

Noria $_{M P}-A_{11}$;

IR (film, $\left.\mathrm{cm}^{-1}\right) ; 3416(v \mathrm{OH}), 2997(v \mathrm{C}-\mathrm{H}$ aromatic), 2932 and 2860 ( $v$ C-H aliphatic), 1737 and 1726 ( $v \mathrm{C}=\mathrm{O}$ ester $), 1619$ and $1588(v \mathrm{C}=\mathrm{C}$ aromatic), 1294 and 1053 ( $v$ C-O-C), 1102( $v$ $\mathrm{O}=\mathrm{C}-\mathrm{O}-\mathrm{C}) .{ }^{1} \mathrm{H}$ NMR (600 $\left.\mathrm{MHz}, \mathrm{CDCl}_{3}, \mathrm{TMS}\right)$ $\delta(\mathrm{ppm})=0.32-2.39\left(\mathrm{~m},-\mathrm{CH}_{3}\right.$ and $\left.-\mathrm{CH}_{2-}, 58.4 \mathrm{H}\right)$, $3.50-3.85\left(\mathrm{~m},-\mathrm{OCH}_{3}, 36 \mathrm{H}\right), 4.23-4.54$ (broad m, $\left.-\mathrm{O}-\mathrm{CH}_{2}-\mathrm{C}=\mathrm{O},>\mathrm{CH}, 14.6 \mathrm{H}\right), 6.21-6.31(\mathrm{~m}, \mathrm{ArH}$, 24H). 7.33 (broad, $-\mathrm{OH}, 10.7 \mathrm{H}$ ). DI $=11 \%$. Yield; $60 \% . \quad M_{\mathrm{n}}=1990, M_{\mathrm{w}} / M_{\mathrm{n}}=1.09$.

Noria $_{M P}-A D_{45}$;

IR (film, $\left.\mathrm{cm}^{-1}\right) ; 3436(v \mathrm{OH}), 2997(v \mathrm{C}-\mathrm{H}$ aromatic), 2920 and 2860 ( $v$ C-H aliphatic), 1749 and $1722(v \mathrm{C}=\mathrm{O}$ ester $), 1610$ and $1586(v \mathrm{C}=\mathrm{C}$ aromatic), 1297 and 1058 ( $v$ C-O-C ether), $1102(v$ $\mathrm{O}=\mathrm{C}-\mathrm{O}-\mathrm{C}$ ester). ${ }^{1} \mathrm{H}$ NMR $\left(600 \mathrm{MHz}, \mathrm{CDCl}_{3}\right.$, TMS $\delta(\mathrm{ppm})=0.33-2.41\left(\mathrm{~m},-\mathrm{CH}_{3}\right.$ and $-\mathrm{CH}_{2-}$, $127.8 \mathrm{H}), 3.51-3.85\left(\mathrm{~m},-\mathrm{OCH}_{3}, 36 \mathrm{H}\right), 4.20-4.55$ (broad $\mathrm{m},-\mathrm{O}-\mathrm{CH}_{2}-\mathrm{C}=\mathrm{O},>\mathrm{CH}, 22.8 \mathrm{H}$ ), 6.21 6.31(m, ArH, 24H). 7.31 (broad, $-\mathrm{OH}, 6.6 \mathrm{H}) . \mathrm{DI}=$ $45 \%$. Yield $=78 \% . \quad M_{\mathrm{n}}=2483, M_{\mathrm{w}} / M_{\mathrm{n}}=1.08$.

Noria $_{M P}-\mathbf{A D}_{53}$;

IR (film, cm $\left.{ }^{-1}\right) ; 3423(v \mathrm{OH}), 2998(v \mathrm{C}-\mathrm{H}$ aromatic), 2919 and 2860 ( $v \mathrm{C}-\mathrm{H}$ aliphatic), 1750 and $1721(v \mathrm{C}=\mathrm{O}$ ester), 1610 and $1586(v \mathrm{C}=\mathrm{C}$ aromatic), 1298 and 1060 ( $v \mathrm{C}-\mathrm{O}-\mathrm{C}$ ether), $1102(v$ $\mathrm{O}=\mathrm{C}-\mathrm{O}-\mathrm{C}$ ester). ${ }^{1} \mathrm{H}$ NMR $\left(600 \mathrm{MHz}, \mathrm{CDCl}_{3}\right.$, TMS $\delta(\mathrm{ppm})=0.26-2.40\left(\mathrm{~m},-\mathrm{CH}_{3}\right.$ and $-\mathrm{CH}_{2}-$, 146.2H), $3.53-3.85\left(\mathrm{~m},-\mathrm{OCH}_{3}, 36 \mathrm{H}\right), 4.24-4.56$ (broad $\left.\mathrm{m},-\mathrm{O}-\mathrm{CH}_{2}-\mathrm{C}=\mathrm{O},>\mathrm{CH}, 24.7 \mathrm{H}\right), 6.20-$ 6.33(m, ArH, 24H). 7.34 (broad, $-\mathrm{OH}, 5.6 \mathrm{H}) . \mathrm{DI}=$ $53 \%$. Yield $=78 \% . \quad M_{\mathrm{n}}=2457, M_{\mathrm{w}} / M_{\mathrm{n}}=1.02$.

Noria $_{M P}-A D_{75}$

IR (film, cm $\left.{ }^{-1}\right) ; 3423(v \mathrm{OH}), 2999(v \mathrm{C}-\mathrm{H}$ aromatic), 2916 and 2860 ( $v \mathrm{C}-\mathrm{H}$ aliphatic), 1749 and 1720 ( $v \mathrm{C}=\mathrm{O}$ ester), 1609 and $1585(v \mathrm{C}=\mathrm{C}$ aromatic), 1298 and 1062 ( $v$ C-O-C ether), $1102(v$ $\mathrm{O}=\mathrm{C}-\mathrm{O}-\mathrm{C}$ ester). ${ }^{1} \mathrm{H}$ NMR $\left(600 \mathrm{MHz}, \mathrm{CDCl}_{3}\right.$, TMS $\delta(\mathrm{ppm})=0.30-2.38\left(\mathrm{~m},-\mathrm{CH}_{3}\right.$ and $-\mathrm{CH}_{2}-$, $189 \mathrm{H}), 3.51-3.83\left(\mathrm{~m},-\mathrm{OCH}_{3}, 36 \mathrm{H}\right), 4.22-4.53$ (broad m, $\left.-\mathrm{O}-\mathrm{CH}_{2}-\mathrm{C}=\mathrm{O},>\mathrm{CH}, 30 \mathrm{H}\right), 6.20-6.30(\mathrm{~m}$, ArH, 24H). 7.33 (broad, $-\mathrm{OH}, 3 \mathrm{H}$ ). DI $=75 \%$. Yield $=85 \% . \quad M_{\mathrm{n}}=2705, M_{\mathrm{w}} / M_{\mathrm{n}}=1.06$.

\section{Patterning property of noria ${ }_{M P}-A D$ by EUV lithography system.}

A solution of PGMEA was prepared from noria $_{\mathrm{MP}}-\mathrm{AD}_{18}(90 \mathrm{wt} \%)$, TPS-Nf as a photo-acid generator $(9 \mathrm{wt} \%)$, and TOA as a quencher $(1 \mathrm{wt} \%)$. The resulting solution was filtered through a 0.45 $\mu \mathrm{m}$ membrane filter and spin-coated on silicon wafer to form thin film with $60 \mathrm{~nm}$ thickness. The film was baked at $130{ }^{\circ} \mathrm{C}$ for $60 \mathrm{sec}$ to remove residual solvent, exposed by small field exposure tool (SFET) with 0.3 mumerical aperture (NA), and re-baked (PEB; post exposure bake) at $130{ }^{\circ} \mathrm{C}$ for $60 \mathrm{sec}$. The exposed film was developed in $2.38 \mathrm{wt} \%$ TMAH aq. for $30 \mathrm{sec}$. The resulting patterns were observed using a CD-SEM (S9220, Hitachi).

\section{Results and discussion}

Synthesis and characteristics of noria $\mathrm{MP} \mathrm{AD}$.

Noria $_{\text {MP }}$ derivatives with pendant adamantyl ester groups (noria $\mathrm{MP}_{\mathrm{P}}-\mathrm{AD}_{\mathrm{n}}$ ) were synthesized by the substitution reaction of noria $\mathrm{MP}_{\mathrm{M}}$ and $\mathrm{BMA}$ in the presence of $\mathrm{K}_{2} \mathrm{CO}_{3}$ and TBAB in NMP (Scheme 1). $\mathrm{By}$ the control of feed ratio, noria ${ }_{\mathrm{MP}}-\mathrm{AD}_{\mathrm{n}}$ with various degrees of introduction of adamantyl ester moieties were synthesized. These conditions and results are summarized in Table 1.

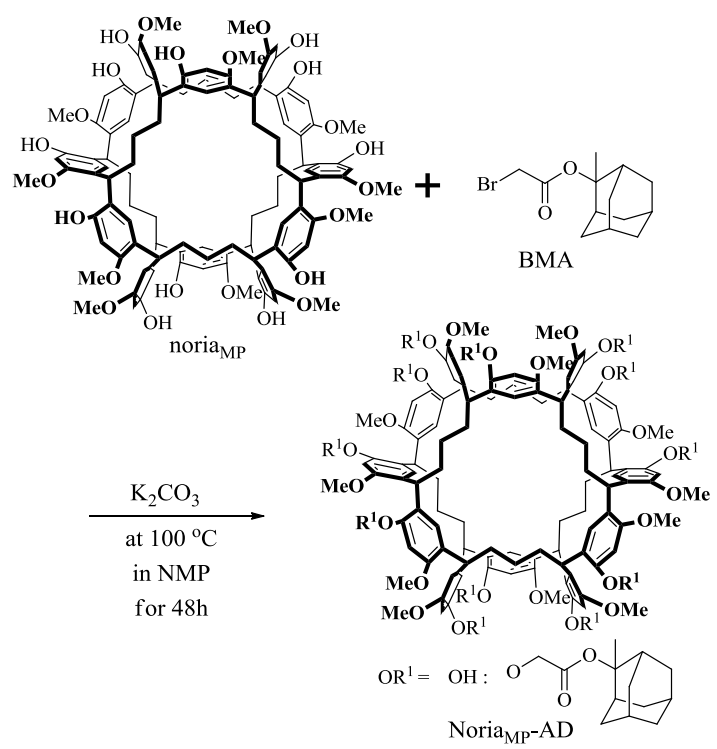

Scheme 1

The structure of noria ${ }_{\mathrm{MP}}-\mathrm{AD}_{\mathrm{n}}$ was confirmed by ${ }^{1} \mathrm{H}$ NMR and IR spectroscopy. Figure 1 depicts the ${ }^{1} \mathrm{H}$ NMR spectrum of noria ${ }_{\mathrm{MP}}$ derivative (run 4 in Table 1), along with that of noria ${ }_{\mathrm{MP}}$. The spectrum shows new peaks assignable to methyl and methylene protons of the $\mathrm{AD}$ moieties at 0.26 $2.40 \mathrm{ppm}$, and indicated that the noria $\mathrm{MP}_{\mathrm{MP}}$ derivative with pendant $\mathrm{AD}$ could be obtained. The degree of introduction of $\mathrm{AD}$ (DI) was calculated from the integration ratios of methyl protons of methoxy moiety of noria $a_{\mathrm{MP}}$ at $3.53 \sim 3.85 \mathrm{pmm}$, and the methyl and methylene protons of the noria ${ }_{\mathrm{MP}}$ and noria $_{\mathrm{MP}}-\mathrm{AD}$ moiety at $0.26 \sim 2.40 \mathrm{ppm}$ in the ${ }^{1} \mathrm{H}$ NMR spectra, and was $53 \%$. Furthermore, FT-IR spectra showed two characteristic absorptions at 1750 and $1102 \mathrm{~cm}^{-1}$ due to $\mathrm{C}=\mathrm{O}$ and $\mathrm{C}-\mathrm{O}-\mathrm{C}$ 
stretching vibrations of adamantyl ester groups, respectively. As the results, noria ${ }_{\mathrm{MP}}-\mathrm{AD}_{\mathrm{n}}$ with $\mathrm{DI}=$ $11 \sim 75 \%$ could be obtained by the control of the feed ratio (Table 1).

Table 1 Synthesis and thermal properties of noria $_{M P}-A D_{n}{ }^{a}{ }^{a}$

\begin{tabular}{|c|c|c|c|c|c|}
\hline \multirow{3}{*}{ run } & Feed ratios & $\mathrm{DI}^{\mathrm{b})}$ & Yield $^{c)}$ & \multirow{3}{*}{$M_{\mathrm{n}}\left(M_{\mathrm{w}} / M_{\mathrm{n}}\right)^{\mathrm{d})}$} & \multirow{3}{*}{$\begin{array}{c}\mathrm{T}_{\mathrm{d}}^{5 \mathrm{e})} \\
{ }^{\mathrm{o}} \mathrm{C}\end{array}$} \\
\hline & $\begin{array}{c}\text { (noria }_{\mathrm{MP}} \\
\mathrm{x} 12\end{array}$ & $(\%)$ & $(\%)$ & & \\
\hline & /BMA) & & & & \\
\hline 1 & $1 / 0.15$ & 11 & 60 & 1990(1.09) & 189 \\
\hline 2 & $1 / 0.30$ & 18 & 68 & $2170(1.09)$ & 179 \\
\hline 3 & $1 / 0.65$ & 45 & 78 & $2480(1.08)$ & 183 \\
\hline 4 & $1 / 0.80$ & 54 & 69 & $2520(1.06)$ & 191 \\
\hline 5 & $1 / 1$ & 75 & 85 & $2710(1.06)$ & 196 \\
\hline
\end{tabular}

${ }^{\text {a) }}$ The reactions of BMA and noria ${ }_{\mathrm{MP}}$ was carried out at various feed ratios in NMP at $60{ }^{\circ} \mathrm{C}$ for 48 hours. ${ }^{\text {b) }} \mathrm{DI}=$ degree of introduction of adamantyl ester groups into noria was calculated from ${ }^{1} \mathrm{H}$ NMR data (see Text).

Methanol-insoluble part. ${ }^{\text {d) }}$ Estimated by SEC(DMF).

e) The temperature of $5 \%$ weight loss $\left(T_{\mathrm{d}}^{5 \%}\right)$ was measured by means of TGA.
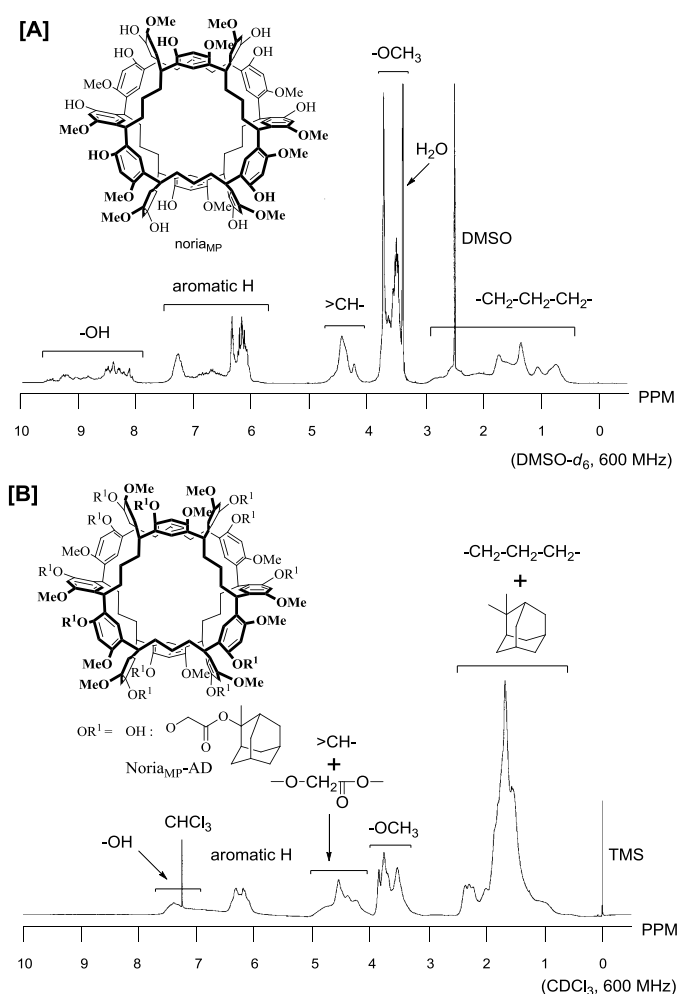

Fig. 1. ${ }^{1} \mathrm{H}$ NMR spectroscopy of noria $_{\mathrm{MP}}$ ([A]) and noria $_{M P}-\mathrm{AD}_{53}([\mathrm{~B}])$ (run 4 in Table 1 ).

Physical properties (solubility, film-forming ability, and thermal stability) of noria ${ }_{M P}-A_{n}$.

The physical properties of synthesized noria $\mathrm{MP}-\mathrm{AD}_{\mathrm{n}}$ were examined to relevant to application as EUV-resist materials.

\section{Solubility.}

Table 2 summarize the solubility characteristics of noria, noria ${ }_{\mathrm{MP}}$, and noria $\mathrm{MP}_{\mathrm{MP}} \mathrm{AD}$. Although, noria was soluble in aprotic highly polar solvents, such as DMSO and DMF, noria ${ }_{\mathrm{MP}}$ was soluble in common organic solvents, such as THF, acetone, and chloroform. This means that hydroxyl groups of noria had replaced with methoxy groups in noria $_{\mathrm{MP}}$, and inter-hydrogen bond effect between hydroxyl groups of the synthesized noria ${ }_{\mathrm{MP}}$ could be reduced. Furthermore, noria ${ }_{\mathrm{MP}}$ derivative with pendant $\mathrm{AD}$ moiety noria $\mathrm{MP}-\mathrm{AD}_{11}(\mathrm{DI}=11 \%)$ was slightly soluble in common organic solvents and soluble in 2.38wt\% TMAH aqueous solution. On the other hand, other noria ${ }_{\mathrm{MP}}-\mathrm{AD}_{\mathrm{n}}(\mathrm{n}=18,45,53$, and 75) were soluble in common organic solvents and insoluble in $2.38 \mathrm{wt} \%$ TMAH aqueous solution. These mean that noria ${ }_{M P}-\mathrm{AD}_{\mathrm{n}}$ with the DI value of more than $18 \%$ could be applicable as positive-type photo-resist material.

Table 2. Solubility of noria, noria $\mathrm{MP}_{\mathrm{MP}}$, and noria $\mathrm{MP}_{\mathrm{MP}}-\mathrm{AD}_{\mathrm{n}}$.

\begin{tabular}{|c|c|c|c|c|}
\hline Solvent & noria & noria $_{M P}$ & $\begin{array}{c}\text { noria }_{M P}-\mathrm{AD}_{11} \\
(\mathrm{DI}=11 \%)\end{array}$ & $\begin{array}{l}\text { noria }_{M P}-A D n \\
(D I=18-75 \%)\end{array}$ \\
\hline Water & - & - & - & - \\
\hline DMSO & ++ & ++ & ++ & ++ \\
\hline DMF & +- & ++ & ++ & ++ \\
\hline Methanol & - & - & - & - \\
\hline THF & - & ++ & ++ & ++ \\
\hline Acetone & - & ++ & ++ & ++ \\
\hline Ethyl lactate & - & +- & +- & ++ \\
\hline Ethyl acetate & - & +- & +- & ++ \\
\hline Ethyl ether & - & - & - & - \\
\hline Chloroform & - & ++ & ++ & ++ \\
\hline PGMEA $^{\text {a) }}$ & +- & ++ & ++ & ++ \\
\hline$n$-Hexane & - & - & - & - \\
\hline Diglyme $^{\text {b) }}$ & - & ++ & ++ & ++ \\
\hline $\mathrm{PGME}^{\mathrm{c})}$ & +- & +- & +- & ++ \\
\hline $\begin{array}{l}2.38 \mathrm{wt} \% \\
\text { TMAH }\end{array}$ & ++ & ++ & + & - \\
\hline
\end{tabular}

${ }^{\mathrm{a})}$ PGMEA $=$ propylene glycol monomethyl ether acetate, ${ }^{\mathrm{b})}$ Diglyme = diethyleneglycol dimethyl ether, ${ }^{\mathrm{c})} \mathrm{PGME}=$ propylene glycol monomethyl ether, ++ ; Soluble at room temperature, + ; Soluble at heating, +- ; Partially soluble, - ; Insoluble 


\section{Film-forming ability.}

The film-forming ability was examined by spin coating a solution of noria $\mathrm{MP}_{\mathrm{P}}$ and noria $\mathrm{MP}_{\mathrm{MP}}-\mathrm{AD}_{\mathrm{n}} 50$ $\mathrm{mg}$ in PEGMEA $1.0 \mathrm{ml}$ in silicon wafer, and drying the wafer in vacuo at room temperature. As the results, all noria $\mathrm{MP}_{\mathrm{P}}-\mathrm{AD}_{\mathrm{n}}$ had good film forming ability. However, noria $\mathrm{MP}-\mathrm{AD}_{11}$ is not candidate for resist material, because it is soluble in TMAH aqueous solution.

\section{Thermal stability.}

The thermal properties of noria ${ }_{\mathrm{MP}}-\mathrm{AD}_{\mathrm{n}}$ were examined by TGA and DSC. The $5 \%$ weight loss temperatures were measured by means of TGA, and were in the range between 179 and 196 ${ }^{\circ} \mathrm{C}$, as summarized in Table 1 . It was shown a tendency of that the thermal stability increased with increasing DI values of noria $a_{M P}-A D_{n}$. This might be because of that acidic phenol groups had been replaced with adamantate groups, i.e., acidic phenol groups promote the thermal decomposition reaction of noria $\mathrm{MP}-\mathrm{AD}_{\mathrm{n}}$. noria ${ }_{\mathrm{MP}}-\mathrm{AD}_{53}$ in the EUV exposure system. Figure 2 depicts the SEM images of the patterns with resolution in the range between 25 and $50 \mathrm{~nm}$, which were obtained using trioctylamine as a quencher at $130{ }^{\circ} \mathrm{C}$ soft bake (SB) temperature and $130{ }^{\circ} \mathrm{C}$ post exposure bake (PEB), and $2.38 \mathrm{wt} \%$ TMAH aqueous solution as $\mathrm{s}$ developer. In the case of noria $\mathrm{MP}^{-}-\mathrm{AD}_{18}$, a clear $50 \mathrm{~nm}$ resolution pattern was obtained with lower exposure dose (8.5 $\left.\mathrm{mJ} / \mathrm{cm}^{2}\right)$ and lower LWR (6.1 nm) compared to those of noria $\mathrm{MP}_{\mathrm{MP}}-\mathrm{AD}_{53}$ (Figure 2[A]). This means that noria $_{\mathrm{MP}}$ derivatives with lower $\mathrm{DI}$ of $\mathrm{AD}$ groups would have higher potential to offer higher resolution pattern. Furthermore, $25 \sim 40 \mathrm{~nm}$ resolution patterns were examined with slightly increased exposure dose. These results also depicts Figure $2[\mathrm{~B}] \sim[\mathrm{F}]$. Clear resolved patterns at 32 $\mathrm{nm}(\mathrm{LWR}=10.5 \mathrm{~nm})$ with dose $=9.0 \mathrm{~mJ} / \mathrm{cm}^{2}$ and $40 \mathrm{~nm}(\mathrm{LWR}=8.9 \mathrm{~nm})$ with dose $=10.0 \mathrm{~mJ} / \mathrm{cm}^{2}$ could be obtained with noria $\mathrm{MP}-\mathrm{AD}_{18}$ and noria $\mathrm{MP}-\mathrm{AD}_{53}$, respectively.

\begin{tabular}{|c|c|c|c|c|c|c|}
\hline & (A) & (B) & (C) & (D) & (E) & (F) \\
\hline $\begin{array}{l}\text { Mask size } \\
\text { L/S (nm) }\end{array}$ & 50 & 40 & 32 & 30 & 28 & 25 \\
\hline Noria $_{M P}-A_{18}$ & & & & & & \\
\hline $\begin{array}{c}\text { Dose } \\
\left(\mathrm{mJ} / \mathrm{cm}^{2}\right)\end{array}$ & 8.5 & 9.0 & 9.0 & 9.0 & 9.0 & 9.0 \\
\hline LER (nm) & 6.1 & 7.7 & 10.5 & - a) & - a) & - a) \\
\hline Noria $_{\mathrm{MP}}-\mathrm{AD}_{53}$ & & & & & & \\
\hline $\begin{array}{c}\text { Dose } \\
\left(\mathrm{mJ} / \mathrm{cm}^{2}\right)\end{array}$ & 10 & 10 & 10.8 & 10.8 & 10.8 & 10.8 \\
\hline LER (nm) & 6.8 & 8.9 & - a) & -a) & - a) & - a) \\
\hline
\end{tabular}

Patterning properties of noria ${ }_{\mathrm{MP}}-\mathrm{AD}$.

Patterning properties were examined using thin-film prepared from noria ${ }_{\mathrm{MP}}-\mathrm{AD}_{18}$ and
Furthermore, the possibility to offer $25 \mathrm{~nm}$ resolution were also found in Figure 2[F]. It is noteworthy that these high resolution patterns 
could be obtained with less than $10 \mathrm{~mJ} / \mathrm{cm}^{2}$, i.e., the sensitivity of resist materials based of noria $_{\mathrm{MP}}-\mathrm{AD}$ is superior compared to our previous reports of noria derivatives noria- $\mathrm{AD}_{23}{ }^{27}$ and noria- $\mathrm{CHVE}_{50}{ }^{28}$. Noria- $\mathrm{AD}_{23}$ and noria-CHVE provided the resist patterns of $26 \mathrm{~nm}$ resolution with exposure dose $=14.5 \mathrm{~mJ} / \mathrm{cm}^{2}$ and $35 \mathrm{~nm}$ resolution with exposure dose $=14.5 \mathrm{~mJ} / \mathrm{cm}^{2}$ in an EUV system, respectively. These results mean that noria $_{\mathrm{MP}}-\mathrm{AD}$ might have high potential to offer higher resolution resist pattern as next-generation EUV-resist materials. Furthermore, the examination resist patterning property of noria ${ }_{\mathrm{MP}}$ and noria $a_{\mathrm{EP}}$ derivatives by the means of interference EUV-exposure system is now under investigation.

\section{Acknowledgment}

This work was supported by a Grant-in-Aid for Scientific Research in Japan (No. 18681015) from the Ministry of Education, Culture, Sports, Science, and Technology and also partly supported by Nano-Space Chemistry for the Creation of Functional Materials at Kanagawa University.

\section{References}

1. J. Fujita, Y. Ohnishi, S. Manako, Y. Ochiai, E. Nomura, T. Sakamoto, and S. Matsui, Jpn. J. Appl. Phys., 36, 7769 (1997).

2. T. Sakamoto, S. Manako, J, Fujita, Y, Ochiai, T. Baba, H. Yamamoto, and T. Teshima, Appl. Phys. Lett., 77, 301 (2000).

3. M. Ishida, J. Fujita, T.Ogura, Y. Ochiai, E. Ohshima, and J. Momoda, Jpn. J. Appl. Phys., 42, 3913 (2003).

4. K. Takeshi, R. Nakayama, and M. Ueda, Chem. Lett., 27, 865 (1998).

5. K. Young-Gil, J.B. Kim, T. Fujigaya, Y. Shibasaki, and M. Ueda, J. Matter. Chem., 12, 53 (2002).

6. M. Ueda, D. Takahashi, T. Nakayama, and O. Haba, Chem. Mater. 10, 2230 (1998).

7. T. Nakayama, K. Haga, O. Haba, and M. Ueda, Chem. Lett. 26, 265 (1997).

8. Y. Ochiai, S. Manako, H. Yamamoto, T. Teshima, J. Fujita, and E. Nomura, J. Photopolym. Sci. Technol., 13, 413 (2000).

9. J. K. Lee, M. Chatzichristidi, A. A. Zakhidov, P. G. Taylor, J. A. DeFranco, H. S. Hwang, H. H. Fong, A. B. Holmes, G. G. Malliaras, and C. K. Ober, J. Am. Chem. Soc., 130, 11564 (2008).

10. S.W. Chang, R. Ayothi, D. Bratton, D. Yang, N. Felix, H. B. Cao, H. Deng, and C. K. Ober, J. Mater. Chem., 16, 1470 (2006).
11. M. Yoshiiwa, H. Kageyama, F. Wakaya, M. Takai, K. Gamo, and Y. Shirota, J. Photopolym. Sci. Technol., 9, 57 (1996).

12. O. Haba, K. Haga, and M. Ueda, Chem. Mater., 11, 427 (1999).

13. T. Fujigaya, Y. Shibasaki, and M. Ueda, $J$. Photopolym. Sci. Technol., 14, 275 (2001).

14. J. Dai, S. W. Chang, A. Hamada, D. Yang, N. Felix, and C. K. Ober, Chem. Mater, 18, 3404 (2006).

15. T. Kadota, H. Kageyama, F. Wakaya, K. Gamo, and Y. Shirota, Chem. Lett., $\quad 33,706$ (2004).

16. T. Nakayama, K. Haga, O. Haba, and M. Ueda, Chem. Lett., 26, 265 (1997).

17. J. B. Kim, H. J. Jun, and Y. G. Kwon, Chem. Lett., 10, 1064 (2002).

18. J. Fujita, Y. Ohnishi, Y. Ochiai, and S. Matui, Appl. Phys. Lett., 68, 1297 (1996).

19. T. Hirayama, D. Shiono, S. Matsumaru, T. Ogata, H. Hada, J. Onodera, T. Arai, T. Sakamizu, A. Yamaguchi, H. Shiraishi, H. Fukuda, and M. Ueda, Jpn. J. Appl. Phys., 44, 5484 (2005).

20. A. D. Silva, N. Felix, J. Sha, J. K. Lee, and C. K. Ober, SPIE, 6923, 69231L (2008).

21. H. Oizumi, K. Tanaka, K. Kawakami, T. Itani, Jpn. J. Appl. Phys 49, 06GF04-1 (2006).

22. H. Kudo, R. Hayashi, K. Mitani, T. Yokozawa, N.C. Kasuga, and T. Nishikubo, Angew. Chem. Int. Ed. 45, 7948 (2006).

23. M. Tanaka, A. Rastogi, H. Kudo, D. Watanage, T. Nishikubo, and C.K. Ober, J. Mater. Chem. 19, 4622 (2009).

24. H. Kudo, D. Watanabe, T. Nishikubo, K. Maruyama, D. Shimizu, T. Kai, T. Shimokawa, and C.K. Ober, J. Mater. Chem. 18, 3588 (2008).

25. X. André, J. K. Lee, A. DeSilva, C.K. Ober, H.B. Cao, H. Deng, H. Kudo, D. Watanabe, and T. Nishikubo, SPIE, 6519, 65194B (2007).

26. T. Nishikubo, H. Kudo, Y. Suyama, H. Oizumi, and T. Itani, J. Photopolym. Sci. Technol., 22, 73 (2009).

27. H. Kudo, Y. Suyama, H. Oizumi, T. Itani, and T. Nishikubo, J. Mater. Chem., 20, 4445 (2010).

28. H. Kudo, M. Jinguji, T. Nishikubo, H. Oizumi, and T. Itani, J. Photopolym. Sci. Technol. 3, 657 (2010).

29. H. Seki, Y. Kato, H. Kudo, H. Oizumi, T. Itani, and T. Nishikubo, Jpn. J. Appl. Phys. 49, 06GF06-1 (2010).

30. T. Kimura, K. Nishino, M. Shimizu, Y. Hirai, K. Maruyama, T. Kai, J. Photopolym. Sci.\& Tech. 23, 643 (2010).

31. N. Niina, H. Kudo, and T. Nishikubo, Chem. Lett. 38, 1198 (2009). 